\title{
Media dan Kekerasan: Analisis Norman Fairclough Terhadap Pemberitaan Tarung Gladiator
}

\author{
Akhirul Annas ${ }^{1}$, Rana Akbari Fitriawan \\ akhirul_annas96@yahoo.com,ranaakbar@telkomuniversity.ac.id
}

\begin{abstract}
Abstrak
Line Today merupakan fitur agregator berita yang terdapat dalam aplikasi Line Messenger. Salah satu berita yang dijadikan Line Today sebagai highligbts pada bulan September 2017 lalu adalah kasus tarung gladiator di kalangan pelajar. Penelitian ini bertujuan untuk mengetahui bagaimana wacana kekerasan dikemas dalam pemberitaan tarung gladiator pada Line Today dengan menggunakan analisis wacana kritis Norman Fairclough untuk menganalisis teks, praktik produksi teks, dan praktik sosial budaya. Dalam penelitian ini digunakan metode kualitatif yang memusatkan perhatian pada prinsip-prinsip umum yang mendasari perwujudan sebuah makna dari gejala-gejala sosial di dalam masyarakat dengan menggunakan paradigma kritis. Paradigma ini memandang bahwa bahasa tidak hanya sebagai alat untuk memahami realitas objektif belaka, tetapi perlu melihat maksud-maksud dari wacana tertentu. Paradigma kritis jauh lebih meneliti aspek sosial, sejarah, dan budaya dari wacana tersebut. Hasil penelitian menunjukkan bahwa Line Today memilih enam berita dari media Kumparan.com, Liputan6.com, dan Okezone.com untuk merekonstruksi kekerasan dalam kasus tarung gladiator di kalangan pelajar. Bahasa yang digunakan dalam teks berita dikemas secara ringan, singkat, dan mudah dipahami oleh generasi milenial.
\end{abstract}

Kata Kunci: Kekerasan, Line Today, Media, Norman Fairclough

\begin{abstract}
Line Today is a news aggregator feature contained in the Line Messenger app. One of the news that Line Today made as highlights in September 2017 was the gladiator fight case among teenage students. This study aims to find out how the discourse of violence is packed in the news gladiator fight on Line Today by using critical discourse analysis Norman Fairclough to analyze text, text production practices, and socio-cultural practices. It used qualitative methods to analyze the meaning of social phenomenon based on critical paradigm. The paradigm noted that language is not only a tool for understanding reality, but it is necessary to look at the intentions of a particular discourse. It used to explore social, historical, and cultural aspects of the discourse. The research shows that Line Today chose six news from media Kumparan.com, Liputan6.com, and Okezone.com to reconstruct the violence in the case of 'tarung gladiator' among teenage students. The language used in the news text is lightly packed, short, and easily understood by millennials generation.
\end{abstract}

Keywords: Line Today, Media, Norman Fairclough, Violence

\footnotetext{
${ }^{1}$ Korespondensi: Akhirul Annas. Telkom University, Jl. Telekomunikasi Terusan Buah Batu, Dayeuh Kolot, Jalan Sukabiru, Sukapura, Dayeuhkolot, Bandung, Jawa Barat 40257. Telp. 082341428899
} 


\section{Pendahuluan}

Kebutuhan warganet di Indonesia terhadap aplikasi obrolan dalam jaringan (daring) atau online cukup tinggi. Salah satu aplikasi obrolan daring yang cukup populer bagi masyarakat Indonesia adalah LINE Messenger atau biasa disebut Line. Jumlah pengguna Line Messenger di Indonesia sekitar 90 juta jiwa di mana 80\% di antaranya adalah pengguna aktif dan didominasi oleh kalangan remaja usia 18 sampai 25 tahun atau biasa disebut generasi milenial.

Kehadiran media daring memiliki dampak positif bagi perkembangan teknologi informasi dan komunikasi. Salah satunya adalah kebiasaan membaca berita. Ketika dahulu khalayak lebih sering mengkonsumsi berita dari media cetak, kini beralih menjadi media daring. Untuk menanggapi perkembangan media daring serta memenuhi kebutuhan khalayak akan jurnalistik daring tersebut, LINE Corporation melakukan sebuah terobosan baru dengan menghadirkan fitur Line Today yang merupakan agregator konten berita (news aggregator).

Salah satu berita Line Today yang sedang hangat diperbincangkan adalah kasus kekerasan di kalangan pelajar pada Januari tahun 2016 lalu yang menimpa seorang pelajar SMA Budi Mulia Bogor, Hilarius Christian Event Raharjo hingga tewas. Kasus tersebut mulai viral akibat unggahan sebuah status Facebook dari ibu korban yang meminta keadilan karena sudah satu tahun lamanya pihak berwenang tidak mengusut kasus tersebut. Fenomena viralnya status Facebook Maria Agnes ini muncul akibat dari perkembangan teknologi komunikasi saat ini yaitu internet. Kehadiran internet pada tahun 1969 membawa pengaruh besar bagi perkembangan teknologi komunikasi. Pada akhir abad ke-20 ditemukan istilah new media atau media baru yang sangat erat kaitannya dengan kehadiran internet.

Line Today selaku pihak agregator konten berita tidak ketinggalan untuk memberitakan kasus Hilarius tersebut. Peneliti melakukan pengamatan pada tanggal 23 September 2017 pukul 10:30 WIB dan menemukan highlights yang berjudul 'Pelajar Tewas Duel 'Gladiator". Dalam highlights tersebut terdapat enam berita yang berasal dari media Kumparan.com, Okezone.com dan Liputan6.com dengan judul dan topik pembahasan yang berbeda-beda.

Kasus duel gladiator adalah peristiwa yang banyak mendapatkan perhatian publik. Berita ini memiliki nilai berita atau news values, salah satunya adalah konflik yang 
memperlihatkan kekerasan di kalangan pelajar. Berita ini menjadi semakin menarik perhatian publik karena menimbulkan korban jiwa. Kasus ini menjadi semakin menarik karena Line Today menyunting beberapa berita dari Kumparan.com, Okezone.com, dan Liputan6.com sehingga dapat disesuaikan dengan pembaca Line Today yang mayoritasnya adalah generasi milenial.

Dalam penelitian ini, peneliti akan menggunakan analisis wacana kritis model Norman Fairclough untuk mengkaji teks, produksi teks, dan praktik sosial budaya dalam kasus kekerasan yang ditampilkan Line Today dalam highlights: 'Pelajar Tewas Duel 'Gladiator' untuk mencari realitas dari wacana sebuah teks berita yang disajikan. Pemilihan Line Today menjadi pertimbangan karena disesuaikan dengan pandangan analisis wacana yang bersifat kritis, selalu memandang teks, percakapan, sebagai praktik nilai-nilai dan pencerminan misi-misi tertentu (Eriyanto, 2001: 12).

Dalam penelitian ini, permasalahan yang ingin dikaji oleh peneliti adalah bagaimana wacana kekerasan dikemas dalam pemberitaan tarung gladiator pada Line Today? Berdasarkan rumusan masalah, maka tujuan penelitian yang ingin dicapai dalam penelitian ini adalah untuk mengetahui bagaimana konstruksi kekerasan yang dikemas dalam pemberitaan tarung gladiator pada Line Today dengan menggunakan metode analisis wacana kritis Norman Fairclough.

\section{Tinjauan Pustaka}

\section{Media Massa}

Media massa adalah alat-alat perantara yang digunakan untuk menyampaikan isi pernyataan kepada khalayak (masyarakat) secara umum, dikelola secara profesional dan bertujuan mencari keuntungan. Dengan demikian, tidak semua media informasi atau komunikasi dapat disebut media massa.

Masyarakat memanfaatkan media massa untuk berbagai keperluan, sesuai dengan fungsi pers. Salah satu bentuk media massa yang cukup populer saat ini adalah media daring (online). Media daring (dalam jaringan) atau online merupakan media yang menggunakan internet. Sepintas lalu orang akan menilai media daring merupakan media elektronik, tetapi para pakar memisahkannya dalam kelompok tersendiri. Alasannya, media daring menggunakan gabungan proses media cetak dengan menulis 
informasi yang disalurkan melalui sarana elektronik, tetapi juga berhubungan dengan komunikasi personal yang terkesan perorangan.

\section{Media Baru}

Media baru merupakan alat atau sarana dalam menyampaikan pesan pada khalayak luas dengan menggunakan teknologi digital atau disebut juga sebagai jaringan teknologi komunikasi dan informasi. Media baru akan terus berkembang seiring kemajuan teknologi komunikasi. Saat ini media baru sudah menjangkau hampir seluruh masyarakat dunia, media baru tersebut dapat dikatakan turut memberi andil yang besar pada perubahan struktur sosial masyarakat. Juga pada sistem media massa.

Dalam media baru (internet), sulit melihat posisi kekuasaan, baik dalam konteks hubungan kepemilikan maupun praktik kekuasaan yang terjadi di dalamnya. Dalam konteks identittas dan integrasi sosial, internet merupakan kekuatan yang dapat membuat khalayak semakin terfragmentasi atau mungkin justru sebaliknya, membentuk kohesi sosial dalam masyarakat. Internet dapat melampaui batas-batas geografis sehingga sebagian mengatakan internet dapat mengakibatkan perubahan.

\section{Media Sosial}

Media sosial merupakan media yang terhubung dengan jaringan internet (networks) di mana para penggunanya dapat berkomunikasi dan berinteraksi dengan pengguna lain tanpa dibatasi oleh ruang dan waktu. Penggunaan media sosial dapat dibagi menjadi dua tipe pengguna, pertama adalah penguna bersifat aktif dan yang kedua adalah pengguna bersifat pasif. Penggunaan bersifat aktif adalah pengguna media sosial yang terlibat dalam interaksi daring dengan pengguna lain melalui berbagai fitur media sosial seperti memberikan komentar pada postingan pengguna lain, memposting foto atau status, atau pun aktivitas lainnya. Pengguna yang bersifat aktif akan melakukan aktivitas-aktivitas tersebut dan dengan leluasa membagikan informasi personalnya. Sebaliknya, pengguna bersifat pasif kurang terlibat dalam interaksi daring. Pengguna yang pasif hanya akan menjelajahi isi halaman media sosial saja, tidak memberikan timbal balik dan tidak berinteraksi dengan pengguna lain.

\section{Teori Ekonomi Politik Media}

Kajian ekonomi politik media berawal dari pengakuan bahwa media adalah sebuah industri yang memproduksi dan mendistribusikan barang-barang yang ditunjang oleh proses integrasi dan diversifikasi. Kajian yang membahas beragamnya 
media tidak dapat dilakukan secara sendiri-sendiri atau tertutup, melainkan harus dipahami dengan konteks ekonomi makro karena keterkaitan media dengan kontrol perusahaan besar atas media.

Sebagai sebuah produk, media memiliki keunikan dibandingkan dengan produk pada manufaktur lainnya, karena media memproduksi dan mereproduksi gambaran kehidupan sosial dan kesadaran kemudian mendistribusikannya kepada konsumen atau yang biasa disebut khalayak. Institusi media memiliki tanggung jawab untuk memenuhi kepentingan publik yang termasuk dalam aspek politik dari media. Media sebagai sebuah industri dituntut untuk terus mengembangkan dirinya dalam kerangka kerja bidang ekonomi, serta ada tuntutan untuk selalu mengikuti perkembangan teknologi dengan mendistribusikan konten melalui banyak platform dalam waktu yang bersamaan.

\section{Analisis Wacana}

Dalam penerapannya ada beberapa sudut pandang dalam menganalisis wacana. Perbedaan sudut pandang ini didasari pada adanya perbedaan pandangan mengenai bahasa. Terdapat tiga pandangan mengenai bahasa dalam analisis wacana, yaitu pandangan pertama diwakili oleh kaum positivisme-empiris. Dalam pendekatan positivisme titik perhatiannya didasarkan pada benar tidaknya bahasa itu secara gramatikal. Pandangan kedua disebut konstruktivisme. Pandangan ini melihat bahwa wacana adalah suatu upaya pengungkapan maksud tersembunyi dari sang subjek yang mengemukakan suatu pernyataan. Pengungkapan itu dilakukan di antaranya dengan menempatkan diri pada posisi sang pembicara dengan penafsiran mengikuti struktur makna dari sang pembicara. Pandangan ketiga disebut sebagai pandangan kritis. Dalam pandangan kritis, wacana dipandang sebagai praktik ideologi, atau pencerminan dari ideologi tertentu. Ideologi yang berada di balik penghasil teksnya akan selalu mewarnai bentuk wacana tertentu.

\section{Analisis Wacana Kritis}

Menurut Faiclough dan Wodak (Eriyanto, 2001: 7), analisis wacana kritis melihat wacana pemakaian bahasa dalam tuturan dan tulisan sebagai bentuk dari praktik sosial. Menggambarkan wacana sebagai praktik sosial menyebabkan sebuah hubungan dialektis di antara peristiwa diskursif tertentu dengan situasi, institusi, dan struktur sosial yang membentuknya. Praktik produksi teks bisa jadi menampilkan efek 
ideologi: ia dapat memproduksi dan mereproduksi hubungan kekuasaan yang tidak imbang antara kelas sosial, laki-laki dan wanita, kelompok mayoritas dan minoritas melalui mana perbedaan itu direpresentasikan dalam posisi sosial yang ditampilkan. Melalui wacana, sebagai contoh, keadaan yang rasis, seksis, atau ketimpangan dari kehidupan sosial dipandang sebagai suatu common sense, suatu kewajaran atau alamiah, dan memang seperti itu kenyataannya.

Analisis wacana kritis melihat bahasa sebagai faktor penting, yakni bagaimana bahasa digunakan untuk melihat ketimpangan kekuasaan dalam masyarakat terjadi. Oleh karena itu, analisis wacana dipakai untuk membongkar kuasa yang ada dalam setiap proses bahasa: batasan-batasan apa yang diperkenankan menjadi wacana, perspektif yang mesti dipakai, topik yang dibicarakan. Dengan pandangan semacam ini, wacana melihat bahasa selalu terlibat dalam hubungan kekuasaan, terutama dalam pembentukan subjek, dan berbagai tindakan representasi yang terdapat dalam masyarakat.

\section{Analisis Wacana Kritis Model Norman Fairclough}

Pendekatan Fairclough dalam menganalisa teks dianggap lengkap karena berusaha menyatukan tiga tradisi yaitu;

1. Dimensi Tekstual (Mikrostruktural), meliputi: representasi, relasi, dan identitas

2. Dimensi Praktik Produksi Teks (Meso-struktural), meliputi: produksi teks, penyebaran teks dan konsumsi teks.

3. Dimensi Praktik Sosial Budaya (Makrostruktural), meliputi: situasional, institusional dan sosial.

\section{Metode}

Penelitian ini dilakukan dengan menggunakan metode penelitian kualitatif dengan pisau bedah analisis wacana kritis yang dikembangkan oleh Norman Fairclough. Pendekatan kualitatif ini memusatkan perhatian pada prinsip-prinsip umum yang mendasari perwujudan sebuah makna dari gejala-gejala sosial di dalam masyarakat (Burhan Bungin, 2007: 23). Penelitian ini disajikan dalam bentuk uraian kata-kata (deskripsi), oleh karena itu digunakanlah metode penelitian kualitatif deskriptif. Metode deskriptif sendiri memiliki pengertian yaitu penelitian yang dirancang untuk mengumpulkan, menganalisa, serta menyajikan data informasi yang 
sebenar-benarnya, penelitian ini dapat memberikan gambaran yang jelas mengenai objek yang diteliti untuk menarik kesimpulan dari objek penelitian.

Penelitian ini menggunakan paradigma kritis yang mempunyai sejumlah asumsi mengenai bagaimana penelitian harus dijalankan, dan bagaimana teks berita seharusnya dianalisis. Paradigma kritis mempunyai pandangan tersendiri pada media, bahwa sebuah berita harus dipahami secara keseluruhan. Dalam pandangan ini, tidak hanya melihat bahasa sebagai alat untuk memahami realitas objektif belaka, tetapi perlu melihat maksud-maksud dari wacana tertentu. Paradigma kritis jauh lebih meneliti aspek sosial, sejarah, dan budaya dari wacana tersebut.

Paradigma kritis diharapkan mampu membentuk kesadaran sosial agar dapat memperbaiki dan mengubah kondisi kehidupan manusia. Oleh karena itu, subjektivitas tidak dapat dihindarkan dalam penelitian ini karena realitas yang ditemukan dalam teks merupakan hasil dari penafsiran peneliti.

\section{Hasil dan Pembahasan}

Tarung gladiator atau yang dikenal dengan tradisi ‘bom-boman' dikalangan pelajar Kota Bogar menjadi viral semenjak unggahan status Facebook Maria Agnes. Dalam status itu, Maria mencurahkan isi hatinya yang ditujukan untuk presiden Jokowi akibat kematian anaknya Hilarius Christian Event Raharjo. Ia merasa sedih dan sakit hati karena sudah setahun lamanya para pelaku kekerasan yang terlibat dalam tarung gladiator tersebut bebas berkeliaran tanpa diusut oleh kepolisian. Pernyataan ini membuat beberapa warganet merasa iba dan mulai membagikan postingan Maria hingga menjadi viral. Kemudian beberapa media televisi, media cetak maupun media online mulai memberitakan kasus tarung gladiator atau tradisi 'bom-boman' tersebut. Akhirnya pihak kepolisian mulai mengusut kembali kasus tersebut dan beberapa hari kemudian polisi berhasil menangkap para pelaku yang membunuh Hilarius.

Line Today sebagai salah satu media agregator konten berita sangat intens memberitakan masalah ini. Jika dilihat kebelakang, kasus ini bermula ketika siswa-siswa dari dua sekolah akan bertanding pada babak final kompetisi basket nasional. Sebelum bertanding di lapangan basket, terlebih dahulu kedua sekolah mewakilkan satu orang untuk bertanding melakukan adu fisik dengan tangan kosong di sebuah lapangan terbuka sambil dikelilingi pelajar lainnya. Dalam highlights 'Pelajar Tewas Duel 
Gladiator' ditampilkan enam berita yang berasal dari media Kumparan, Okezone.com, dan Liputan6.com. Respon pembaca dalam kolom komentar memperlihatkan bahwa mereka sangat mengecam aksi ini dengan mengumpat para pelaku menggunakan gaya bahasa kekinian ala generasi milenial.

Dalam merekonstruksi kekerasan yang dikemas dalam pemberitaan tarung gladiator pada Line Today digunakan metode analisis wacana kritis Norman Fairclough. Adapaun penjelasan dari analisis tersebut adalah sebagai berikut:

\section{Analisis Teks (Mikro)}

Fairclough membagi analisis wacana teks menjadi tiga elemen dasar untuk menguraikan dan menganalisis setiap teks yaitu representasi, relasi, dan identitas.

1) Representasi

Hasil analisis keenam berita yang terdapat dalam highlights Pelajar Tewas 'Duel' Gladiator pada Line Today, peneliti menemukan bahwa wacana kekerasan yang direpresentasikan dalam teks merupakan wacana yang digunakan untuk menggambarkan peristiwa kekerasan dalam tarung gladiator di kalangan pelajar kota Bogor. Mulai dari sejarah tarung gladiator, kronologi tewasnya Hilarius dalam kasus tarung gladiator, proses otopsi, sampai dengan tertangkapnya para pelaku yang bertanggung jawab atas meninggalnya Hilarius yaitu BV, HK, MS, dan TB. Terdapat tiga alat yang digunakan untuk merepresentasikan kekerasan dan tokoh yang terlibat, yaitu melalui diksi, penggunaan kalimat luas sebab akibat, dan mengutip langsung pernyataan narasumber. Dalam mewacanakan kekerasan, Kumparan.com, Okezone.com, dan Liputan6.com cenderung lebih berpihak kepada korban. Ini terlihat dari penggunaan diksi mencekam, mengerikan, dan memprihatinkan yang memiliki makna eksplisit untuk menggambarkan kondisi korban akibat ulah para pelaku yang begitu keji dalam aksi tarung gladiator.

2) Relasi

Wacana dalam teks berita menggambarkan proses pengusutan kasus tarung gladiator yang masuk dalam ranah hukum sebagai tindakan menghilangkan nyawa seseorang dengan sengaja, dilakukan secara beramairamai, dan menyalahi aturan hukum sehingga perlu ditegakkan keadilan yang berpusat pada pihak kepolisian. Proses penyelesaian hukum perlu dilakukan 
oleh polisi sesuai dengan fungsi mereka yaitu memelihara keamanan dan ketertiban masyarakat, menegakkan hukum, serta memberikan perlindungan, pengayoman, dan pelayanan kepada masyarakat.

Kehadiran ayah Hilarius yaitu Venansius Raharjo dan ibundanya yaitu Maria Agnes dalam teks ingin menunjukkan bahwa ada sebuah kekecewaan yang mereka alami terhadap pihak kepolisian karena terlambat dalam mengusut kasus kekerasan yang menimpa anaknya. Kemudian mereka juga menunjukkan kesedihan yang mendalam akibat kepergian Hilarius sehingga tidak bisa mewujudkan cita-citanya untuk berkuliah di jurusan Teknik Mesin ITB.

Ditampilkannya narasumber tambahan yaitu Tanto, Tyo, dan Danu yang merupakan mantan siswa SMA swasta di Jakarta memberikan penjelasan tambahan tentang sejarah tarung gladiator yang dulunya bernama 'partai' hingga berubah menjadi tarung gladiator.

3) Identitas

Kumparan.com, Okezone.com, Liputan6.com sebagai mitra Line Today yang memproduksi teks dalam highlights Pelajar Tewas 'Duel' Gladiator mencoba menggambarkan situasi, kondisi, latar, dan peristiwa yang cenderung lebih pro terhadap korban. Peristiwa ini hanya melibatkan orang tua korban, polisi, dan mantan siswa SMA swasta Jakarta sebagai narasumber. Terlihat penulis berita tidak menampilkan pelaku dalam teks untuk memberikan klarifikasi atas tindakan kekerasan yang mereka lakukan. Dari keseluruhan berita tentang tarung gladiator yang dianalisis, memperlihatkan bahwa penulis berita mengambangkan kasus ini seolah-olah kasus ini adalah sebuah hal biasa, karena banyak kasus serupa yang terjadi di dunia pendidikan Indonesia.

\section{Analisis Praktik Produksi Teks (Meso)}

LINE Messenger memiliki jumlah pengguna aktif di Indonesia sebesar 90 juta jiwa di mana 80\% dari keseluruhan penggunanya adalah generasi milenial. Berdasarkan hasil survey Dailysocial.id dan JakPad dengan responden sebanyak 1012 orang mengenai kebiasaan pembaca berita di Indonesia 2017, ditemukan bahwa Line Today mendapat posisi kedua setelah Facebook dengan perolehan respon sebesar $50,64 \%$ sebagai pilihan warganet Indonesia untuk mendapatkan informasi berita 
terbaru. Data tersebut menunjukkan bahwa Line Today menjadi salah satu alternatif ketika warganet Indonesia sedang ingin mencari berita terbaru ataupun ketika sedang memiliki waktu luang.

Walaupun Line Today tidak memiliki tim redaksi seperti redaktur, wartawan, editor, dan lain-lain layaknya media massa pada umumnya, bukan berarti Line Today asal dalam memilah dan memilih berita dari berbagai sumber. Rangkaian produksi teks yang dilakukan Line Today pada highlights: 'Pelajar Tewas Duel 'Gladiator” edisi 23 September 2017 pukul 10:13 WIB merupakan rangkaian institusional yang melibatkan tim kurator untuk menyunting seluruh berita yang ingin dipublikasikan pada aplikasi. Tim kurator inilah yang bertanggung jawab atas konten berita yang disampaikan kepada pembaca agar terhindar dari berita palsu atau hoax.

Setiap berita yang dipilih Line Today telah melalui proses produksi teks atau kegiatan ruang redaksi. Tahapan selanjutnya yaitu proses pemilahan dan pemilihan berita terbaru oleh tim kurator Line Today. Pada akhirnya terpilihlah enam berita yang terdiri dari empat berita oleh media Kumparan.com, satu berita oleh media Okezone.com, dan satu berita oleh media Liputan6.com untuk mewacanakan kasus kekerasan di kalangan pelajar. Media tersebut cukup kredibel dan populer dikalangan masyarakat.

Kemudahan dan kepraktisan Line Today dalam memberikan informasi secara cepat dan singkat tanpa dibatasi ruang dan waktu, membuat setiap berita yang ditampilkan Line Today selalu mendapat respon dari pembaca baik itu pro atau kontra terhadap suatu isu. Hal tersebut dapat diamati melalui kolom komentar pembaca yang disediakan oleh fitur Line Today. Ada yang mengeluh dan memprotes isi berita yang disuguhkan karena tidak layak serta tidak bermutu, ada yang memberikan respon positif terhadap suatu berita, ada yang saling beradu argumen, ada yang mempromosikan sebuah produk, ada pula yang komentar ujaran kebencian dan SARA, serta komentar-komentar unik lainnya dengan gaya bahasa ala anak generasi milenial. Inilah yang disebut sebagai pengguna media sosial yang aktif, yang selalu merespon terhadap suatu konten. Adapun respon warganet terhadap kasus kekerasan dalam tarung gladiator ini kebanyakan mengecam akan aksi yang dilakukan oleh pelajar kota Bogor tersebut. 


\section{Analisis Praktik Sosial Budaya (Makro)}

Praktik sosial budaya merupakan interpretasi dari praktik produksi teks. Setiap teks dalam wacana dipengaruhi oleh faktor ekonomi, politik (kekuasaan dan ideologi), dan budaya (nilai dan identitas) yang mempengaruhi institusi media. Fairclough membuat tiga level analisis pada praktik sosial budaya:

1) Tingkat Situasional

Setiap media massa akan mengangkat sebuah fenomena atau peristiwa yang mempunyai nilai berita. Tentunya berita-berita tersebut dianggap penting karena layak untuk disajikan kepada khalayak. Perisitiwa-peristiwa yang memiliki nilai berita ini misalnya mengundang konflik, keganjilan, buman interest, seks, dan aneka nilai lainnya.

Kekerasan tentunya tidak luput dari pandangan media. Media memandang bahwa kekerasan adalah sebuah bahan pemberitaan yang layak untuk disajikan kepada khalayak. Konflik fisik seperti yang dialami Hilarius dalam tradisi tarung gladiator memiliki nilai berita yang layak karena pemberitaan tentang kekerasan tersebut merupakan sebuah eksploitasi dari penderitaan manusia.

Peristiwa ini juga menjadi perhatian bagi banyak media, termasuk Line Today tidak ketinggalan untuk memberitakan kasus ini. Berita ini memperlihatkan konflik kekerasan di kalangan pelajar yang dapat disesuaikan dengan emosi pengguna LINE yaitu generasi milenial.

2) Tingkat Institusional

Penulisan teks pemberitaan 'Tarung Gladiator di Kalangan Pelajar' melibatkan pihak kepolisian sebagai narasumber yaitu Kombes Ulung Sampurna Jaya selaku Kapolresta Bogor Kota. Dengan hadirnya narasumber dalam teks, Line Today mencoba untuk memberitahu pembaca bahwa kasus kekerasan di kalangan pelajar terjadi lagi bahkan sampai merenggut korban jiwa.

Sebenarnya kematian Hilarius adalah kasus lama yang terjadi di tahun 2016, namun pihak keluarga tidak bersedia melakukan otopsi sehingga pihak kepolisian tidak bisa melanjutkan kasus ini. Padahal prosedur otopsi ini perlu dilakukan sebagai landasan perlu tidaknya penyelidikan lebih lanjut oleh pihak 
berwajib. Hal tersebut demi terpenuhinya rasa keadilan dan mendapatkan kepastian hukum. Satu tahun berselang, pihak keluarga akhirnya memberikan izin kepada penyelidik untuk melakukan otopsi terhadap jenazah Hilarius dan terungkaplah kasus ini.

Sesuai dengan Visi Polri yaitu 'Termujudnya pelayanan keamanan dan ketertiban masyarakat yang prima, tegaknya bukum dan keamanan dalam negeri yang mantap serta terjalinnya sinergi polisional yang proaktif. Maka polisi berperan dalam menegakkan keadilan atas kasus ini, sehingga para pelaku berhasil ditangkap dan mendapatkan kepastian hukum. Adapun pihak keluarga Hilarius akhirnya mendapatkan keadilan.

Sangat disayangkan bahwa dalam teks tidak menampilkan pihak Kementerian Pendidikan dan Kebudayaan (Kemendikbud). Padahal pihak yang seharusnya bertanggung jawab atas kasus kekerasan dikalangan pelajar adalah Kemendikbud. Dalam Peraturan Menteri Pendidikan dan Kebudayaan (Permendikbud) Nomor 82 tahun 2015 tentang Pencegahan dan Penanggulangan Tindak Kekerasan di Lingkungan Satuan Pendidikan, setiap sekolah harus membentuk gugus pencegahan kekerasan yang terdiri dari guru, siswa dan orang tua. Peraturan yang dibuat oleh Kemendikbud sebagai regulator tersebut belum efektif dijalankan karena masih banyaknya kasus kekerasan yang terjadi di kalangan pelajar. Jika melihat kasus tarung gladiator, kondisi SMA Budi Mulia dan SMA Mardi Yuana jauh dari suasana proses pembelajaran yang aman, nyaman dan menyenangkan. Setiap tahunnya, para junior dihantui rasa takut karena kasus tarung gladiator ini sudah berlangsung selama empat tahun dan dilakukan secara turun-temurun. Mereka dipaksa untuk terlibat dalam tindakan kekerasan yaitu melakukan duel satu lawan satu dengan siswa sekolah lain.

Seharusnya seluruh pelaku pendidikan mengambil peran pengawasan dalam penanggulangan tindak kekerasan di kalangan pelajar. Sekolah dapat mengambil peran melakukan pengawasan langsung di sekolah. Adapun pemerintah kabupaten, kota, maupun provinsi mengambil peran dalam pengawasan jenjang pendidikan dasar sampai dengan menengah. Kasus tarung gladiator yang menyebabkan Hilarius meninggal dunia menggambarkan bahwa 
pihak Kemendikbud, Sekolah, dan Pemerintah lengah dalam melakukan pengawasan dan pencegahan tindakan kekerasan di kalangan pelajar, karena kasus tarung gladiator ini sudah berlangsung selama empat tahun.

3) Tingkat Sosial

Setiap insan manusia yang lahir di dunia telah membawa hak-hak dasar yang diberikan oleh Tuhan Yang Maha Esa atau biasa disebut dengan hak asasi manusia. Setiap orang berhak atas semua hak dan kebebasan dalam menjalani hidup, tanpa memandang suku, agama, ras, warna kulit, dan perbedaan lainnya. Hak ini tidak akan pernah lepas dan terus melekat sampai akhir hayat.

Perlindungan terhadap anak adalah segala kegiatan untuk menjamin dan melindungi hak-haknya agar dapat berkembang dan terus tumbuh sesuai dengan harkat dan martabat kemanusiaan, serita mendapar perlindungan dari diskriminasi dan kekerasan.

Kekerasan yang diakibatkan oleh kenakalan remaja tidak dapat dilepaskan dari konteks kondisi sosial budaya zamannya. Sebab setiap era memiliki ciri khas masing-masing, dan memberikan jenis tantangan khusus kepada generasi mudanya, sehingga anak-anak muda ini mereaksi dengan cara yang khas pula terhadap kondisi sosial yang ada.

Sebenarnya anak-anak remaja yang ikut-ikutan mengambil bagian dalam aksi perkelahian antar sekolah, yang acapkali secara tidak sadar melakukan tindak kriminal dan antisosial itu pada umumnya adalah anak-anak normal yang berasal dari keluarga baik-baik dan disekolahkan di tempat yang baik pula (Kartini Kartono, 2014: 104). Dengan pengaruh lingkungan yang buruk ditambah dengan kontrol diri dan kontrol sosial remaja yang semakin melemah, dapat mempercepat pertumbuhan kekerasan di kalangan pelajar. Oleh karena itu untuk mengatasi persoalan kekerasan di kalangan pelajar merupakan tanggung jawab orang tua, keluarga dan seluruh elemen masyarakat.

Pengaruh sosial dan kultural memainkan peranan besar dalam menentukan tingkah laku kenakalan para remaja. Sama halnya dengan kasus kekerasan yang dialami Hilarius merupakan peristiwa minimnya konformitas (penyesuaian) anak-anak remaja terhadap norma sosial yang tengah berlaku. Mereka sangat terpengaruh oleh stimuli sosial yang jahat seperti pengaruh 
lingkungan yang buruk. Jika melihat kasus tarung gladiator ini, yang memberikan pengaruh buruk terhadap junior adalah senior-senior mereka sendiri. Karena sudah menjadi budaya turun-temurun, mereka tidak mampu mengenal dan memahami tingkah lakunya yang buruk, juga tidak mampu mengendalikan dan mengaturnya. Setiap tahunnya selalu saja mereka ingin melakukan perbuatan kekerasan, penyerangan dan kejahatan.

Jika melihat kondisi sosial diatas, Line Today sebagai agregator berita tertarik untuk mewacanakan kasus kekerasan ini. Line Today berusaha menggiring opini pembaca bahwa sebagai media agregator berita, mereka selalu mengikuti perkembangan isu sosial yang terjadi di sekitar masyarakat Indonesia, dan berusaha untuk menyuarakan keadilan seperti dalam pemberitaan tarung gladiator. Line Today memandang bahwa kasus kekerasan yang diwacanakan dalam media dapat menarik perhatian pembaca dan bisa meningkatkan keuntungan dengan memasang iklan.

\section{Kesimpulan}

Pada bagian ini peneliti akan menyajikan kesimpulan dari hasil penelitian yang telah dilakukan. Kesimpulan bertujuan untuk merumuskan hasil dari penelitian dan pembahasan yang sudah dijelaskan sebelumnya guna menjawab pokok masalah yang merupakan tujuan akhir dari penelitian ini. Berdasarkan analisis yang telah dilakukan, maka peneliti memiliki kesimpulan dalam penelitian ini: Pertama, dari segi analisis teks. Dari berbagai alat kebahasaan yang digunakan Kumparan.com, Okezone.com, dan Liputan6.com dalam highlights Pelajar Tewas Duel 'Gladiator' Line Today pada dasarnya ingin menunjukkan kepada pembaca bahwa ada sebuah kasus menarik yaitu kekerasan di kalangan pelajar dan dapat disesuaikan dengan segmentasi Line yaitu generasi milenial. Terdapat tiga alat yang digunakan untuk merepresentasikan kekerasan dan tokoh yang terlibat, yaitu melalui diksi, penggunaan kalimat luas sebab akibat, dan mengutip langsung pernyataan narasumber.

Dalam mewacanakan kekerasan, Line Today cenderung lebih berpihak kepada korban. Ini terlihat dari penggunaan diksi mencekam, mengerikan, dan memprihatinkan yang memiliki makna eksplisit untuk menggambarkan kondisi korban akibat ulah para pelaku yang begitu keji dalam aksi tarung gladiator. Secara keseluruhan 
keenam berita yang dipilih Line Today memiliki benang merah yang sama antara satu berita dengan berita yang lain. Dengan kata lain Line Today ingin mewacanakan kekerasan yang ditampilkan oleh tiga media yang dia pilih yaitu Kumparan, Okezone.com dan Liputan6.com. Peneliti menemukan banyaknya pengulangan informasi di setiap paragraf, namun dikemas secara baik dengan permainan gaya bahasa yang bervariasi. Jika melihat segi kualitas dan kuantitas, pemberitaan mengenai kekerasan dalam kasus tarung gladiator di kalangan pelajar ini lebih cenderung ringan, singkat, dan mudah dipahami untuk pembaca generasi milenial.

Kedua, dari segi analisis praktik produksi teks. Untuk merepresentasikan wacana kekerasan dalam pemberitaan tarung gladiator, tim kurator Line Today memutuskan untuk menampilkan enam berita dari media Kumparan.com, Liputan6.com, dan Okezone.com. Pemilihan ketiga media tersebut telah melalui berbagai pertimbangan dalam ruang institusional. Pertama, media Kumparan.com, Liputan6.com, dan Okezone.com pasti melakukan kegiatan redaksi sebelum memproduksi teks. Selanjutnya masuk ke tahap pemilahan dan pemilihan berita oleh tim kurator Line Today. Karakteristik pembaca yang didominasi oleh generasi milenial yang aktif dalam menggunakan media sosial membuat tim kurator melakukan pertimbangan yang baik untuk mengkonstruksikan kasus tarung gladiator ini.

Ketiga, dari segi analisis praktik sosial budaya. Keputusan Kumparan.com, Liputan6.com dan Okezone.com sebagai pihak yang memproduksi teks dalam highlights 'Pelajar Tewas Duel 'Gladiator' pada Line Today ini dipengaruhi oleh kondisi masalah sosial berupa kenakalan remaja yang semakin memprihatinkan. Citra dunia pendidikan Indonesia tercoreng hanya karena ulah segelintir siswa yang melakukan aksi kekerasan antar pelajar hingga menyebabkan korban jiwa. Salah satunya adalah kasus tarung gladiator yang menyebabkan kematian Hilarius. Aksi tersebut sebenarnya sudah dilakukan secara turun-temurun sebagai ajang adu gengsi demi menjaga nama baik almamater sekolah. Keterlibatan polisi dalam teks untuk mengungkapkan kasus ini memberikan sebuah titik terang bagi orang tua korban. Kasus yang sebenarnya terjadi di tahun 2016 akhirnya diusut kembali sampai pada akhirnya para pelaku berhasil ditangkap dan mendapatkan status hukum. 


\section{Referensi}

\section{Buku}

Badara, Aris. (2012). Analisis Wacana: Teori, Metode, dan Penerapannya Pada Wacana Media. Jakarta: Kencana.

Bugin, Burhan. (2007). Penelitian Kualitatif: Komunikasi, Ekonomi, Kebijakan Publik, Dan Ilmu Sosial Lainnya. Jakarta: Kencana.

Darma, Aliah Yoce. (2014). Analisis Wacana Kritis Dalam Multiperspektif. Bandung: PT. Refika Aditama.

Eriyanto. (2001). Analisis Wacana: Pengantar Analisis Teks Media. Yogyakarta: LkiS. Fairclough, Norman. (1995). Critical Discourse Analysis: The Critical Study of Language. Harlow-Essex: Longman Group Limited.

Kartono, Kartini. (2010). Patologi Sosial 2: Kenakalan Remaja. Jakarta: PT. Raja Grafindo Persada.

McQuail, Denis. (2011). Teori Komunikasi Massa McQuail, Edisi 6 Buku 1. Jakarta: Salemba Humanika.

Moleong, Lexy J. (2007). Metodologi Penelitian Kualitatif. Bandung: Remaja Rosdakarya.

Mondry. (2008). Pemahaman Teori dan Praktik Jurnalistike (Edisi Kedua). Bogor: Ghalia Indonesia.

Nasrullah, Rulli. (2014). Teori dan Riset Media Siber (Cybermedia). Jakarta: Kencana.

Nasrullah, Rulli. (2015). Media Sosial: Perspektif Komunikasi. Budaya, dan Sosioteknologi.

Bandung: Simbiosa Rekatama Media.

Santana, Septian K. (2005). Jurnalisme Kontemporer. Bandung: Yayasan Obor Indonesia.

Soehoet, A.M. Hoeta. (2002). Manajemen Media Massa. Jakarta: Yayasan Kampus Tercinta-IISIP.

Vera, Nawiroh. (2016). Komunikasi Massa. Bogor: Ghalia Indonesia.

\section{Jurnal}

Ayatullah, Alda Laseta. (2014). Korupsi Dalam Wacana Pers Lokal (Analisis Wacana Kritis Norman Fairclough Terbadap Teks Berita Kasus Hambalang Tabun 2013 Pada Surat Kabar Malang Post). Diakses pada 23 Oktober 2017 pukul 11.28 melalui http://media.neliti.com. 
Keller, Margit. (2014). Positioning Consumption: A Practice Theoretical Approach to Contested Consumption and Media Discourse. SAGE, Vol. 14(I) 35-51. Diakses pada 16 Oktober 2017 pukul 11.54 melalui http://journals.sagepub.com.

Munfarida, Elya. (2014). Analisis W acana Kritis Dalam Perspektif Norman Fairclough. ISSN: 1978-1261. Diakses pada 16 November 2017 pukul 16.50 melalui ejournal.iainpurwokerto.ac.id/index.php/komunika/article/view/746

\section{Artikel Daring}

Line Today (2017). Cerita Sang Ayah Soal Jenazah Hilarius yang Masih Utuh, diakses pada tanggal 23 September 2017 pukul 10.13 melalui http://today.line.me/ID/pc/article/Cerita+Sang+Ayah+soal+Jenazah + Hilarius+yang+Masih+Utuh-vk1lyK

Line Today (2017). Dari 'Partai' ke Duel Gladiator: Aksi Unjuk Gengsi Anak SMA 2000-an, diakses pada tanggal 23 September 2017 pukul 10.13 melalui: https://today.line.me/ID/pc/article/Dari+Partai+ke+Duel+Gladiator + Aksi+Unjuk+Gengsi+Anak+SMA+2000+an-Xj2JVe?

Line Today (2017). Highlights Pelajar Tewas 'Duel' Gladiator pada Line Today edisi 23 September 2017 pukul 10:13 WIB.

Line Today (2017). Hilarius Bercita-Cita Kuliah di Jurusan Teknik Mesin ITB, diakses pada tanggal 23 September 2017 pukul 10.14 melalui: https://today.line.me/ID/pc/article/Hilarius+Bercita+Cita+Kuliah+di +Jurusan+Teknik+Mesin+ITB-P9L9x0

Line Today (2017). Tentang Tradisi Duel Gladiator di Sekolah yang Menewaskan Hilarius, diakses pada tanggal 23 September 2017 pukul 10.14 melalui: https://today.line.me/ID/pc/article/Tentang+Tradisi+Duel+Gladiator +di +Sekolah+yang+Menewaskan+Hilarius-L6QRMj?

Line Today (2017). Ternyata Tarung 'Gladiator’ di Bogor Sudah Berlangsung Selama 4 Tahun, diakses pada tanggal 23 September 2017 pukul 10.14 melalui: https://today.line.me/ID/pc/article/Terungkap+Tarung+Gladiator+di +Bogor+Sudah+Berlangsung+Selama+4+Tahun-pGW7mw?

Line Today (2017). Tiap Sekolah Wakilkan 5 Pelajar untuk Duel ala Gladiator di Bogor, diakses pada tanggal 23 September 2017 pukul 10.14 melalui: 
https://today.line.me/ID/pc/article/Tiap+Sekolah+Wakilkan+5+Pelaj ar+untuk + Duel+ala + Gladiator + di + Bogor-r3r5JP? 